\title{
Transparency, Civic Capital and Political Accountability: A Virtuous Relation?
}

\section{Giuseppe Albanese $^{1}$ | Emma Galli ${ }^{2}$ | Ilde Rizzo ${ }^{3}$ | Carla Scaglioni ${ }^{4}$}

\author{
${ }^{1}$ Bank of Italy, Catanzaro Branch, Catanzaro \\ Largo Serravalle, Catanzaro, 1-88100 \\ ${ }^{2}$ Department of Social and Economic \\ Sciences, Sapienza University of Rome, \\ Piazzale Aldo Moro -00100, Roma \\ ${ }^{3}$ Department of Economics and Business, \\ University of Catania Corso, Catania, 55- \\ 95129, Italia \\ ${ }^{4}$ DiGiES, Mediterranean University of Reggio, \\ Calabria Via dei Bianchi, Reggio Calabria, 2- \\ 89127
}

\begin{abstract}
Our paper investigates the intertwined relation among transparency, civic capital and political accountability in a large sample of Italian municipalities using a new indicator of institutional transparency. Firstly, we test the hypothesis that civic capital affects transparency of public administrations; secondly, we verify whether in municipalities where civic capital is high, citizens' attention toward government accountability is also high, making it politically unfeasible to disregard the demand for transparency. We find that civic capital positively affects transparency and the latter, in turn, is politically rewarding for the local administrators only conditional to the level of civic capital. Our findings are robust to different samples and endogeneity concerns.
\end{abstract}

\section{1 | INTRODUCTION}

Fostering transparency is one of the policies undertaken in contemporary democracies to monitor the performance of the public administrations, promote the integrity of public officials and favor accountability (OECD, 2015). Transparency represents a useful tool to address the problems of information asymmetry characterizing the relationship between the principal, i.e., the stakeholders, and the agent, i.e., policy makers, whose interests may indeed be conflicting (Heald, 2006). On the one hand, making available clear and free information on public activities, transparency may lower for citizens the costs of getting informed, reducing free-riding and enhancing their monitoring capability (Aguiar-Conraria et al., 2019). On the other hand, sharing a set of values which goes beyond narrow self-interest,

\footnotetext{
We acknowledge that this paper is a research outcome of the project MIUR PRIN 2017 - 2017CRLZ3F "PolitiCanti. The Politicisation of Corruption and Anticorruption Strategies in Italy". We would like to thank Guglielmo Barone, Hillel Rapoport, Paolo Sestito, Leonzio Rizzo, Juan S. Morales, the Editor (David Stadelmann), two anonymous referees and seminar participants in Varese (SIEDS 2018), Firenze (AIQUAV 2018), Jerusalem (EPCS 2019), Rio de Janeiro (Global Conference on Transparency Research 2019), Torino (SIEP 2019) and Palermo (SIE 2019) for useful comments and suggestions. We are deeply indebted to Luigi Guiso for kindly sharing his data. The views in this paper are those of the authors and do not necessarily represent the views of any institution with which they are affiliated. A previous version of this paper was circulated with the title "Building the Glass House: Transparency and Civic Capital across Italian municipalities".
} 
citizens are more inclined to get informed and avoid free-riding attitudes. As recent behavioral studies suggest (Bault et al., 2017; Kamei et al., 2019), interactions among individuals activate social preferences, giving rise to a relational system that strengthens the community. Where a sense of community does exist, individual interactions get stronger, information is likely shared and, therefore, participation to public life increases, leading public actors to be more accountable. In this perspective, the quality of the social environment seems to affect transparency and its impact on political accountability. In other words, transparency, civic capital and accountability appear intertwined in the literature but, to the best of our knowledge, the relationship among them has not been fully explored so far. Therefore the novelty of our contribution is to investigate whether the effects of transparency on political accountability are conditioned by the degree of civic capital.

We develop our empirical analysis in two steps: firstly, we verify the hypothesis that civic capital positively affects transparency of public administrations, addressing potential endogeneity; then, we test whether in environments where civic capital is high, citizens' attention toward government accountability is higher, making politically unfeasible to disregard the demand for transparency.

To this end, we firstly estimate a model where the Composite Transparency Index (CTI) - a new indicator of institutional transparency constructed on a completely new data set (Galli et al., 2017) - is regressed over a few indicators of civic capital and several other controls. We find that civic capital positively affects transparency. Then, we verify whether transparency is politically rewarding for the mayor or whether it is so only conditional to the level of civic capital. Our results provide evidence that the political payoff of being transparent is positively affected by the degree of civic capital.

The rest of the paper is organized as follows. In Section 2 we briefly present the survey of the related literature; in Section 3 we summarize the issue of measuring transparency. Section 4 presents the empirical analysis of the relation between civic capital and transparency. Section 5 provides some evidence of relation among transparency, civic capital and political payoff. Section 6 concludes the paper.

\section{2 | RELATED LITERATURE}

Our paper merges two different strands of literature, one that examines the determinants and effects of transparency, and the other that investigates the relationship between civic capital and political accountability.

\section{1 | Determinants and effects of transparency}

Different approaches (economics, law, political science, public administration) have addressed the issue of transparency, focusing on a plurality of aspects such as measurement, determinants, associations with several outcomes, i.e. improvement of public administrations' performance, reduction of corruption, increase of accountability, citizens' trust and civic capital. ${ }^{1}$

A line of research has empirically investigated the demographic (size of population, age, gender), socio-economic (digital divide, education, fiscal aggregates, income, income distribution, unemployment,) and political (ideology, party competition, turnout) determinants of transparency in several countries using different measures of transparency (see, among others, Bertelli \& Pietrowsky, 2010; Albalate del Sol, 2013; Araujo \& Tejedo-Romero, 2016).

Other empirical studies have focused on the relation between transparency and several features such as trust in public institutions, participation to public life, and civicness, showing that these connections are generally positive, even though context-dependent (see, among others, Welch et al., 2005; Piotrowski \& Van Ryzin, 2007; de Fine Licht et al., 2014; Grimmelikhuijsen \& Meijer, 2014).

${ }^{1}$ See on these aspects a recent and exhaustive review by Cucciniello et al. (2016). 
Finally, as regards the effects of transparency, another branch of literature has investigated to what extent transparency is an effective tool of accountability and whether its effectiveness depends on the characteristics of the community (i.e., Piotrowski \& Van Ryzin, 2007) and on the policy area and layer of government (Etzioni, 2010, 2014; Meijer et al., 2015; Porumbescu, 2015). In some cases, for instance, the effects are negative as transparency generates immobility and malfunctioning of the public administration (Grumet, 2014).

\subsection{Civic capital and political accountability}

The sociological and economic literature has developed several definitions of social capital which take into account one or more horizontal (social norms, shared community values, trust among people, social networks, memberships in associations, civic engagement) and vertical (trust towards institutions, political participation) dimensions. ${ }^{2}$ The line of research we follow in this study focuses on the horizontal dimension of social capital, considering civic involvement and common goals' sharing as important prerequisites for an active and vigilant citizenry (see, among others, the seminal work by Putnam, 1993).

A few contributions have focused on the link between civic capital and political accountability. Using data on Flemish municipalities, Jottier and Heyndels (2012) found a positive nexus between perceived quality of government and election results of the incumbent parties, which is stronger in municipalities characterized by high civic capital. Nannicini et al. (2013) argued that civic voters who share a set of values have higher expectations about the standards of politicians' behavior and therefore are more likely to punish corrupt or lazy politicians. Using Italian national data, they found that voters' punishment of politicians' misbehaviors is indeed considerably larger in districts where civic capital is higher. Giordano and Tommasino (2013), measuring public sector efficiency for several public services for 103 Italian provinces, showed that civicness reduces political rents because citizens' expectations about politicians' behavior are higher and keeping the incumbent politicians accountable is easier. Similarly, Albanese et al. (2019), exploring the relationship between civic capital across Italian regions and the electoral reform of 2005, found that the effects of the electoral rules on politicians' behavior vary according to the level of civic capital characterizing different districts. Finally, Batinti et al. (2019) showed that an incumbent mayor who has adopted investment-oriented and property tax-oriented fiscal policies is more likely to be rewarded by voters in municipalities characterized by a higher level of civic capital.

To the best of our knowledge, these two strands of literature have remained separate so far and missed to investigate the intertwined relationship among transparency, civic capital and political accountability.

\section{3 | MEASURING TRANSPARENCY}

Over the last three decades, the interest in the construction and use of governance indicators has led to a burgeoning production of corruption (Sequeira, 2012) and transparency (although to a lesser extent) indicators (Cucciniello et al., 2016). This proliferation of measures has encouraged a growing complexity in both data gathering and methodologies, but also raised significant criticisms regarding the method through which corruption and transparency have been defined and operationalized (Malito, 2014).

As regards measuring transparency in Italy, ${ }^{3}$ Galli et al. (2017) have built a composite indicator (CTI) based on the transparency obligations requested to the public administration since the 2013 legislation. ${ }^{4}$ Specifically, the CTI

${ }^{2}$ For a recent survey on the concept of social capital, see de Blasio et al. (2014).

${ }^{3} \mathrm{~A}$ web-portal managed by the Italian government, the so-called "Compass of Transparency" offers information only on whether public administrations' websites follow the format ("Transparent Administration" - Amministrazione Trasparente) prescribed by law but does not allow to monitor their content. Fadda et al. (2018) use this limited measure of transparency to show that there is an inverse correlation between levels of corruption and public administration's commitment to transparency. With respect to a sample of 525 municipalities, Pernagallo and Torrisi (2020) find that the "Compass of Transparency" overestimates their compliance. 
is the average of a set of items concerning two dimensions of the public action: "integrity" (comprising items on income, asset disclosure and conflict of interest for both politicians and top and senior public officials) and "performance" (encompassing items on the management of public property, the timeliness of public payments, and the quality of public services). ${ }^{5}$ The CTI is built on a completely new first-hand dataset including information on the integrity and management of municipality activities, published on the municipality websites (in the section Amministrazione Trasparente). The value of each item is based on the evaluation provided by an Independent Evaluation Unit (Organismo Indipendente di Valutazione - OIV) along the criteria established by the National Anticorruption Authority (Autorità Nazionale Anticorruzione - ANAC 6 ), i.e. "publication of information", "completeness", "updating" and "openness". The scale goes from 0 to 3 , except for "publication of information" which ranges from 0 to 2; for the purpose of the computation, the items are re-scaled from 0 to 3 . Values are normalized, and the average for all indices is set equal to unity. Then, the values for each sub-pillar are recalculated in relation to the average and given equal weights, consistent with the ANAC methodology. ${ }^{7}$

It is worth noting that this methodology is replicable in any context where public administrations are requested to engage in the active disclosure of information through regulated obligations. As regards Italy, the indicator is tested on a large sample of municipalities and calculated for 2013 , the first year of implementation of the new transparency regulations. The indicator's robustness is showed by its high correlation with widely used measures provided for the Italian context, for the quality of institutions, ${ }^{8}$ the municipalities' performance (Galli et al., 2017) ${ }^{9}$ as well as for the equitable and sustainable well-being (Galli et al., 2019). ${ }^{10}$

\section{4 | ESTIMATING THE RELATIONSHIP BETWEEN CIVIC CAPITAL AND TRANSPARENCY}

In this section, we first aim to verify the relationship between civic capital and transparency empirically. In particular, the following formula is used:

$$
\text { Transparency }_{i}=\alpha+\beta * \text { CivicCapital }_{i}+\gamma * \text { Controls }_{i}+\varepsilon_{i}
$$

where our measure of transparency in city $i$ is regressed over civic capital and a set of control variables. Transparency is measured with the CTI index built by Galli et al. (2017), as described in Section 3.

The CTI index is available for 524 municipalities (Galli et al., 2020). Almost four-fifths are drawn from a stratified sample of municipalities with less than 15,000 inhabitants selected by ANAC (2015) for its monitoring activities. In addition, all the provincial capital cities are also included, in order to take into account in the analysis a set of larger cities disseminated across Italy. Accordingly, our final sample covers $6.5 \%$ of Italian towns, which represent $32 \%$ of the population. Figure 1 shows the spatial distribution of CTI index. Transparency is on average higher in the Centre and North municipalities, but there is substantial variability across space, which we exploit in our empirical model.

\footnotetext{
${ }^{5}$ Integrity and efficiency, however, are closely related in the public sector: fostering integrity indeed favors cost-effective controls and improves efficiency (OECD, 2017).

${ }^{6} \mathrm{ANAC}$ resolution $\mathrm{n} .77 / 2013$.

${ }^{7}$ For further details, see Galli et al. (2017).

${ }^{8}$ The Institutional Quality Index (IQI) (Nifo \& Vecchione, 2014) is a well-established synthetic indicator of institutional quality for Italian provinces, capturing the major characteristics of a governance system. The Spearman's rank correlation coefficient between CTI and IQI is 0.87 (the Pearson coefficient is slightly lower, 0.75 ).

${ }^{9}$ The Quantitative Level of Service provision (QLS) is a synthetic measure of performance of public spending at municipal level based on official data (SOSE, 2016). The Spearman's rank correlation coefficient between CTI and QLS is 0.84 (the Pearson coefficient is slightly lower, 0.78).

${ }^{10} \mathrm{CTI}$ shows a good correlation with some Equitable and Sustainable Well-Being Indicators (Istat, 2014): Internet use intensity and trust in institutions (0.66); social participation (0.52); women's participation in municipal councils (0.50). The correlation is weaker with civic and political participation (0.46) and voter turnout for European elections (0.15).
} 
FIGURE 1 Transparency (CTI index). Note: CTI measures the degree of transparency across the sample (see Table A2 for a description)

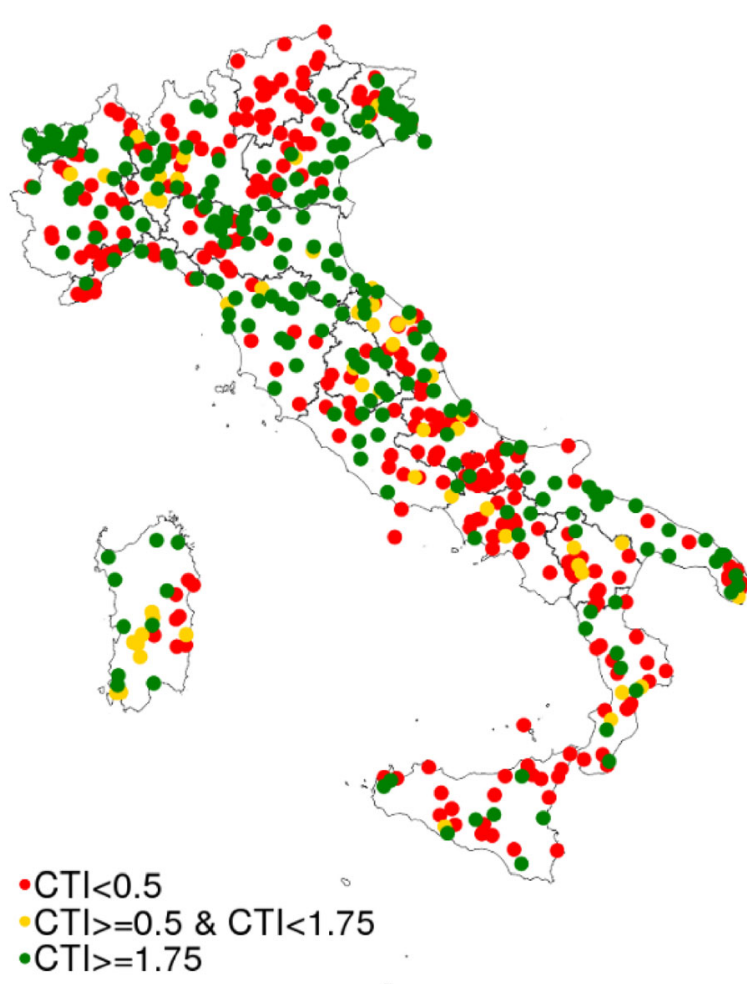

In this paper, we focus on the dimension of civic capital, defined as "those persistent and shared beliefs and values that help a group overcome the free rider problem in the pursuit of socially valuable activities" (Guiso et al., 2011:3). We consider three conventionally accepted proxies for measuring civic capital (Putnam, 1993; Guiso et al., 2008, 2016): (a) the average turnout at referenda held in the period 1974-1985; (b) the (log) number of non-profit organizations per capita; (c) the existence of an organ donation organization at the city level. The correlation among these measures is positive, even if far from perfect (see Table A1 in the Supplementary Information). For this reason, we rely on a principal component analysis to build our baseline index of civic capital, while maintaining the other variable as robustness check. Figure 2 reports the spatial distribution of our preferred index. This map confirms the divide between the Centre-Northern and the Southern Italian regions already highlighted in the literature (Barone \& de Blasio 2010; Cartocci \& Vanelli 2015; Bigoni et al., 2016). The spatial distribution of civic capital, indeed, is related to many factors, such as the historical legacy (Banfield, 1958; Putnam, 1993) and the characteristics of local socioeconomic context (Rupasingha et al., 2006; Guiso et al., 2011).

The relationship between transparency and civic capital could be driven by several confounding factors. Therefore, our OLS estimates in Section 4.1 take into account a wide set of (socio-economic, fiscal, politico-institutional, and geographical) control variables selected according to the literature on the determinants of transparency (Galli et al., 2017, 2019). Table 1 illustrates the summary of the statistics of the variables employed in our study, while a description of the variables used, and the relative sources, is available in the SI (Table A2). Again, in Section 4.2 we attempt to correct for other sources of endogeneity using an IV estimator.

\section{1 $\quad$ OLS Results}

In this section, we report our OLS equation estimates (1). Table 2 indicates the baseline specifications. The measure of civic capital is the first principal component of referenda turnout, density of non-profit organizations and the 


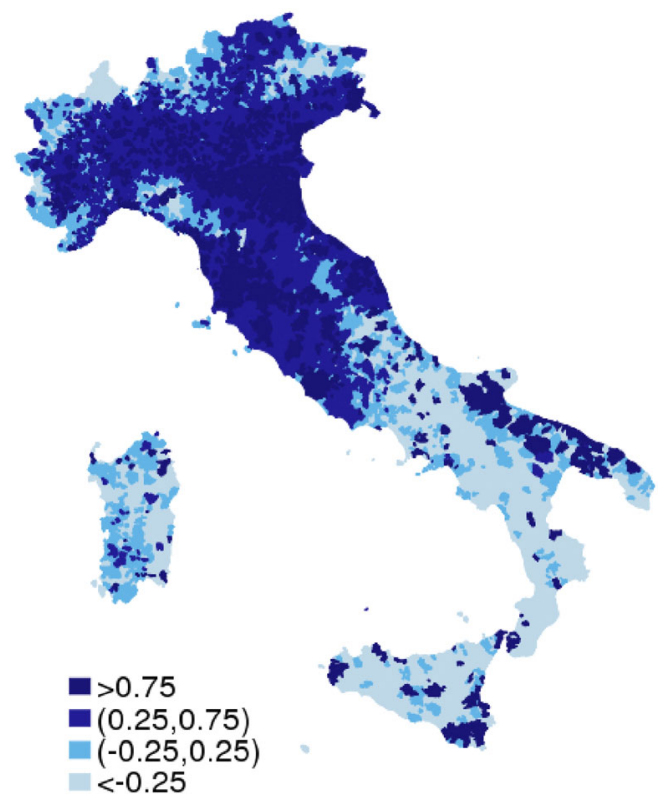

FIGURE 2 Civic Capital Index. Note: Civic Capital Index is the first principal component of referenda turnout, (log) number of non-profit organizations per capita and a dummy for the existence of an organ donation organization (AIDO)

TABLE 1 Descriptive statistics

\begin{tabular}{|llllll|}
\hline & Mean & S.D. & Min & Max & Obs. \\
\hline CTI & 1.01 & 1.15 & 0 & 3.64 & 524 \\
\hline Civic Capital Index & 0.00 & 1.14 & -5.27 & 2.41 & 524 \\
\hline Referenda Turnout & 0.79 & 0.10 & 0.53 & 0.93 & 524 \\
\hline (Log) Non-profit organizations per capita & 1.48 & 0.82 & -5.94 & 4.18 & 524 \\
\hline Organ donors & 0.18 & 0.39 & 0 & 1 & 524 \\
\hline & Baseline covariates & & & \\
\hline Population (in thousands of inh.) & 37.75 & 155.97 & 0.04 & $2,752.02$ & 524 \\
\hline Education & 0.37 & 0.09 & 0.08 & 0.62 & 524 \\
\hline Income (in thousands of euro) & 21.35 & 3.62 & 12.95 & 36.59 & 524 \\
\hline Gini inequality in income & 0.39 & 0.04 & 0.27 & 0.52 & 524 \\
\hline Digital divide & 0.19 & 0.31 & 0 & 1 & 524 \\
\hline Elevation & 358.98 & 327.88 & 1 & 1,699 & 524 \\
\hline Coastal location & 0.14 & 0.34 & 0 & 1 & 524 \\
\hline South & 0.39 & 0.49 & 0 & 1 & 524 \\
\hline
\end{tabular}

Note: see Table A2 for a description.

existence of an organ donors organization. In our most parsimonious model (Column 1), we consider population and its square as the only covariates. Column 2 uses a wider set of controls for the socio-economic and geographic characteristics of municipalities (population and its square, ratio of people with secondary education, average income, Gini income inequality, digital divide, elevation, coastal location, and a dummy for the Southern municipalities) which the above-mentioned literature identifies as determinants of transparency. In the (baseline) Column 3 , we add 
TAB LE 2 The effect of civic capital on transparency (baseline OLS results)

(1)

\begin{tabular}{|llll|}
\hline Civic Capital Index & $0.326^{* * *}(0.042)[0.000]$ & $0.287^{* * *}(0.059)[0.000]$ & $0.253^{* * *}(0.068)[0.000]$ \\
\hline Population & $0.004^{* * *}(0.001)[0.000]$ & $0.003^{* * *}(0.001)[0.002]$ & $0.003^{* * *}(0.001)[0.002]$ \\
\hline Population squared & $-0.000^{* * *}(0.000)[0.000]$ & $-0.000^{* * *}(0.000)[0.001]$ & $-0.000^{* * *}(0.000)[0.001]$ \\
\hline Education & & $2.284^{* * *}(0.811)[0.049]$ & $2.071^{* *}(1.012)[0.065]$ \\
\hline Income & & $0.022(0.025)[0.543]$ & $0.026(0.028)[0.406]$ \\
\hline Gini & & $-2.900^{* *}(1.262)[0.054]$ & $-0.634(1.228)[0.661]$ \\
\hline Digital divide & $-0.074(0.134)[0.656]$ & $-0.089(0.148)[0.625]$ \\
\hline Elevation & & $-0.000^{*}(0.000)[0.356]$ & $-0.000(0.000)[0.614]$ \\
\hline Coastal location & & $0.214(0.157)[0.220]$ & $0.191(0.160)[0.146]$ \\
\hline South FE & $\mathrm{N}$ & $\mathrm{Y}$ & $\mathrm{N}$ \\
\hline Region FE & $\mathrm{N}$ & $\mathrm{N}$ & $\mathrm{Y}$ \\
\hline $\mathrm{R}^{2}$ & $\mathrm{~N}$ & 0.286 & 0.386 \\
\hline $\mathrm{N}$ & 524 & 524 & 524 \\
\hline
\end{tabular}

Note: ${ }^{*} \mathrm{p}<0.1,{ }^{* *} \mathrm{p}<0.05,{ }^{* * *} \mathrm{p}<0.01$.

CTI represents the dependent variable and measures the degree of transparency across the sample. Civic Capital Index is the first principal component of referenda turnout, (log) number of non-profit organizations per capita and a dummy for the existence of an organ donation organization (AIDO). Robust standard errors in parentheses ( $p$-value with spatial HAC correction in brackets, assuming a 100 miles maximum radius).

regional fixed effects to control for unobserved region-specific factors. Since transparency has been shown to be spatially correlated (Galli et al., 2020), we also report standard errors corrected using Conley's (1999) method.

Overall, the results support the existence of a positive and significant relationship between civic capital and the degree of transparency adopted at the municipal level. ${ }^{11}$ Our estimated (baseline Column 3 ) coefficient implies that a standard deviation increase in our index of civic capital is associated with an increase in CTI by about $25 \%$ of its average.

We run a number of robustness checks to further gauge the relevance of omitted variable bias. ${ }^{12}$ In Table 3 (Column 1) we exclude the municipalities in Special Statute Regions (Valle d'Aosta, Trentino Alto Adige, Friuli Venezia Giulia, Sardegna and Sicilia) in order to consider a more homogeneous sample. In Table 3 (Columns 2-3), we add additional controls to disentangle the effect of civic capital from the quality of local institutions. In particular, Column 2 includes fiscal autonomy (the percentage of own taxes over the total revenues, as a proxy for accountability) and fiscal efficiency (the municipality capability of disposal of residual liabilities), while Column 3 adds also a measure of effectiveness of public governance (available only for the subsample of cities in Regions with Ordinary Statute). ${ }^{13}$ Again, Table 3 (Column 4) includes a set of political features: individual characteristics of the mayor that could be related to the level of transparency (age, gender and education); a dummy variable taking the value of 1 if the ruling mayor belongs to a left-wing party and 0 otherwise; a dummy variable taking the value of 1 if the mayor is

\footnotetext{
${ }^{11}$ Table A3 in the Supplementary Information (SI) shows that our results are not driven by the different measures of civic capital.

${ }^{12}$ In order to assess the robustness of our results to omitted variable bias, we have also applied the test proposed by Oster (2019). This method assess the validity of OLS estimates under the assumption that the selection on the observed control variables is proportional to the selection on the unobserved ones. In our case, however, the test is only partially conclusive, since it assures the robustness of results only to moderate deviations from the standard assumption of absence of unobserved confounding factors. Indeed, to nullify the impact of civic capital, the effect of the unobservable factors needs to be roughly $20 \%$ of that of the observable ones.. Therefore, to better cope with the issue of the unobservable confounding factors, we have implemented an IV analysis (see Section 4.2).

${ }^{13}$ We consider a measure of the capacity of the municipality to satisfy the demand for services expressed by their citizens, taking into account the expenditure and the level of services compared to the standard values. Data are taken from: https://www.opencivitas.it/. For further details regarding the relationship between transparency and municipalities' performance see Galli et al. (2017).
} 
TAB LE 3 The effect of civic capital on transparency (robustness checks)

(1)

(2)

(3)

(4)

(5)

\begin{tabular}{|c|c|c|c|c|c|}
\hline Civic Capital Index & $0.240^{* * *}(0.072)$ & $0.252^{* * *}(0.068)$ & $0.228^{* * *}(0.073)$ & $0.248^{* * *}(0.068)$ & $0.176^{* *}(0.069)$ \\
\hline Population & $0.004^{* * *}(0.001)$ & $0.003^{* * *}(0.001)$ & $0.004^{* * *}(0.001)$ & $0.003^{* * *}(0.001)$ & $0.002^{* *}(0.001)$ \\
\hline $\begin{array}{c}\text { Population } \\
\text { squared }\end{array}$ & $-0.000^{* * *}(0.000)$ & $-0.000^{* * *}(0.000)$ & $-0.000^{* * *}(0.000)$ & $-0.000^{* * *}(0.000)$ & $-0.000^{* * *}(0.000)$ \\
\hline Education & $2.291^{*}(1.182)$ & $2.089^{* *}(1.012)$ & $2.747^{* *}(1.218)$ & $2.075^{* *}(1.013)$ & $2.462^{* *}(1.040)$ \\
\hline Income & $0.002(0.033)$ & $0.027(0.029)$ & $-0.001(0.033)$ & $0.023(0.029)$ & $0.042(0.029)$ \\
\hline Gini & $-1.411(1.554)$ & $-0.657(1.233)$ & $-2.268(1.607)$ & $-0.651(1.253)$ & $-1.571(1.272)$ \\
\hline Digital divide & $0.002(0.172)$ & $-0.100(0.151)$ & $0.031(0.180)$ & $-0.076(0.150)$ & $-0.028(0.149)$ \\
\hline Elevation & $-0.000(0.000)$ & $-0.000(0.000)$ & $-0.000(0.000)$ & $-0.000(0.000)$ & $-0.000(0.000)$ \\
\hline Coastal location & $0.210(0.198)$ & $0.197(0.159)$ & $0.180(0.212)$ & $0.189(0.163)$ & $0.075(0.159)$ \\
\hline Fiscal autonomy & & $-0.059(0.262)$ & $-0.426(0.324)$ & & \\
\hline Fiscal efficiency & & $0.225(0.270)$ & $0.115(0.323)$ & & \\
\hline $\begin{array}{l}\text { Effectiveness of } \\
\text { governance }\end{array}$ & & & $0.064^{* *}(0.028)$ & & \\
\hline Age Mayor & & & & $0.002(0.004)$ & \\
\hline Gender Mayor & & & & $-0.092(0.129)$ & \\
\hline Education Mayor & & & & $0.159^{*}(0.085)$ & \\
\hline Political party & & & & $0.030(0.109)$ & \\
\hline Second term & & & & $0.002(0.099)$ & \\
\hline Region FE & Y & Y & Y & Y & Y \\
\hline $\mathrm{R}^{2}$ & 0.366 & 0.386 & 0.377 & 0.390 & 0.416 \\
\hline $\mathrm{N}$ & 399 & 524 & 385 & 524 & 524 \\
\hline
\end{tabular}

Note: ${ }^{*} \mathrm{p}<0.1,{ }^{* *} \mathrm{p}<0.05,{ }^{* * *} \mathrm{p}<0.01$.

CTI represents the dependent variable and measures the degree of transparency across the sample. Civic Capital Index is the first principal component of referenda turnout, (log) number of non-profit organizations per capita and a dummy for the existence of an organ donation organization (AIDO). In Column 1, the municipalities in Special Statute Regions (Valle d'Aosta, Trentino-Alto Adige, Friuli Venezia Giulia, Sardegna and Sicilia) are excluded. Column 5 includes covariates selected by the "double-lasso" variable selection procedure (Belloni et al., 2014) among the 31 socio-economic census variables reported in the Appendices (Table B), their squared terms and their interaction with a dummy for Southern municipalities. Robust standard errors in parentheses.

allowed to run a second term and 0 otherwise. Finally, in Table 3 (Column 5) we have considered a potential set of socio-economic variables (31 characteristics from 2001 census data, their squared terms and interaction terms with a dummy for the Southern municipalities); ${ }^{14}$ to avoid overfitting, the regression includes only the covariates selected using the "double-lasso" variable selection procedure proposed by Belloni et al. (2014). ${ }^{15}$ In general, these results confirm the previous evidence.

\subsection{Results}

Our OLS results support the existence of a relationship between civic capital and transparency in the Italian public administrations. However, there are a number of important reasons to be cautious in interpreting this result as

\footnotetext{
${ }^{14}$ See Table A4 in the Appendices for a description of the variables used.

${ }^{15}$ We selected a subset of covariates by using a Least Absolute Shrinkage and Selection Operator (LASSO), which minimizes the sum of squared residuals and an additional penalty parameter that aims to reduce the overall size of the model.
} 
causal. First, civic capital may be measured with error, corresponding poorly with its true value. This may create an attenuation bias leading the linear estimates downward. Second, better administered cities may be characterized by a greater sense of civic duty; this potential reverse causality problem may introduce positive bias in the linear estimates. Third, there are many omitted determinants of institutional quality that may be correlated with civicness. Therefore, in this section, we estimate an IV specification to provide evidence for a causal nexus between civic capital and transparency.

Following a long research tradition (Putnam, 1993; de Blasio \& Nuzzo, 2010; Bracco et al., 2015; Albanese \& de Blasio, 2016; Guiso et al., 2016), we considered that the current civic behavior in Italy has strong historical roots, due to the long-term persistence of civicness. More specifically, the medieval experience of self-government promoted the formation of civic capital, which has persisted until today. Accordingly, in our IV analysis we have used two historical instruments for civic capital in northern Italian cities taken from Guiso et al. (2016): ${ }^{16}$ a dummy equal to one if the municipality was a free city-state ("Commune") in the Middle Ages, and a dummy equal to one if the municipality became an independent "Signoria" during the 15th century. Guiso et al. (2016: 1406) emphasize that "the Communes made their rules, laws, and formal decisions in the name of the people, because political power was said to derive from the people, not from some religious authority or divine right". Similarly, the Signoria preserved the key institutions of the Commune, as well as the principle that power derived from the people and must be exercised in the people's name. Therefore, the free city-states experience has fostered "the formation of a different culture, which has persisted to these days and still affects the level of civic capital" (Guiso et al., 2016: 1432).

Both these measures are strongly correlated with the current level of civic capital. However, in order to be considered good instruments, this (first stage) condition is not sufficient; the historical variables indeed must correlate with the CTI index only through civic capital, which technically is referred to as the condition of the orthogonality of the instrument to the (second stage) error term. There are a number of reasons to suggest that this is a fair assumption to make. First, the long-term determinants of civic capital remove any simultaneity bias caused by local shocks that occurred in more recent history. For such simultaneity to remain, we would need these past local shocks to have influenced both medieval experience of independence and other city characteristics related to the transparency performance currently observed in Italy. This seems to be hard to believe, as many major events contributed to the abrupt changes in the structure of Italy's economy and society (Malanima 2005, 2011). Second, the condition might be violated if some missing permanent municipality's characteristics drove both the history of cities and their current transparency performance. However, we directly control in our regressions for the most relevant geographic characteristics and for population size, which differentiate the potential sources of violation of the condition related to both people's agglomeration and mobility across the national territory. Again, we address later in this section some potential issues with this identification strategy.

Table 4 illustrates our IV results. Column 1 confirms our previous OLS evidence when we restrict the analysis only to the Centre-North sub-sample, for which the instruments are feasible. Column 2 reports 2SLS results where our index of civic capital is instrumented by the two historical variables on medieval political institutions. The evidence supports the existence of a causal effect of civic capital on the degree of transparency. The usual tests corroborate the credibility of our IV specification. In particular, the first stage F-tests confirm the existence of a strong correlation between historical variables and current civic capital, already demonstrated by Guiso et al. (2016). ${ }^{17}$ Again, Sargan tests for over identifying restrictions do not reject the hypothesis that the model is correctly specified, and the instruments used are valid. Finally, the coefficient of the 2SLS estimator is larger, showing that OLS results underestimate the effect of civic capital on transparency.

In what follows, we discuss some threats to our exclusion restriction. Our baseline specification includes regional fixed effect based on current political borders. Yet, they barely correspond to historical political borders that

\footnotetext{
${ }^{16}$ To our knowledge, alternative instruments based on historical traditions of civicness are available only at the provincial level (de Blasio \& Nuzzo, 2010; Di Liberto \& Sideri, 2015), while Bracco et al. (2015) exploits a unique historical event concentrated in a few areas in southern Italy.

${ }^{17}$ Indeed, the first stage F-tests are always higher than the critical values of Stock and Yogo (2005), reassuring us that the weak instruments issues do not apply in our case.
} 
TAB LE 4 The effect of civic capital on transparency (IV results)

\begin{tabular}{|c|c|c|c|c|c|}
\hline & (1) & (2) & (3) & (4) & (5) \\
\hline Civic Capital Index & $0.249^{* * *}(0.093)$ & $0.786^{* * *}(0.283)$ & $0.773^{* * *}(0.286)$ & $0.726^{* * *}(0.265)$ & $0.959^{* * *}(0.285)$ \\
\hline Estimator & OLS & IV & IV & IV & IV \\
\hline $\begin{array}{l}\text { Additional } \\
\text { Covariates }\end{array}$ & None & None & $\begin{array}{l}\text { Dummies Past } \\
\text { Dominations }\end{array}$ & $\begin{array}{l}\text { Years Past } \\
\text { Dominations }\end{array}$ & $\begin{array}{l}\text { Historical } \\
\text { Levels of } \\
\text { Urbanization }\end{array}$ \\
\hline First stage F-test & & 19.8 & 19.2 & 21.2 & 19.3 \\
\hline $\begin{array}{l}\text { Sargan over } \\
\text { identification } \\
\text { test ( } p \text {-value) }\end{array}$ & & 0.877 & 0.994 & 0.973 & 0.768 \\
\hline $\mathrm{N}$ & 319 & 319 & 319 & 319 & 319 \\
\hline
\end{tabular}

Note: ${ }^{*} \mathrm{p}<0.1,{ }^{* *} \mathrm{p}<0.05,{ }^{* * *} \mathrm{p}<0.01$.

Regressions were run on the sample of cities located in the Center-North of Italy. CTI represents the dependent variable and measures the degree of transparency across the sample. Civic Capital Index is the first principal component of referenda turnout, (log) number of non-profit organizations per capita and a dummy for the existence of an organ donation organization (AIDO). The instruments are a dummy equal to 1 if the town was a free city-state ("Commune") in the Middle Ages and a dummy equal to 1 if the town was an independent "Signoria" (source: Guiso et al., 2016). All the regressions include the baseline covariates (see Table 2) and Region FE. Column 3 includes five dummies which capture the domination whose influence was predominant at the provincial level: Spanish, Papal, Austrian, Venetian, Sabaudian (source: Di Liberto \& Sideri, 2015). Column 4 includes 9 variables which measure the number of years that the following regimes have persisted at the provincial level in the period that spans from 1,100 to 1861: Norman, Swabian, Anjou, Spanish, Bourbon, Papal, Sabaudian, Austrian and Venetia (source: Di Liberto \& Sideri, 2015). Column 5 includes 7 variables measuring population at the following points of time: 1300, 1,400, 1,500, 1,600, 1700, 1800 and 1861 (source: Malanima, 1998). Robust standard errors in parentheses.

characterized the pre-unification history of Italy. In fact, before the first half of the 19th century, Italy was fragmented into several states with administrative entities that were largely changing across the time. Often, they reflect the foreign colonizations experienced by different areas of the country over the centuries. In our context, this may matter if such past dominations persistently influenced political institutions. For example, the Spanish domination in Italy was in many ways oppressive: fiscalism, which has always been excessive, became even more intolerable in the Seventeenth century, when the weight of the costs of military campaigns was largely discharged on the Italian citizens (De Luca, 2012). Spain was also identified as the armed arm of the Counter-Reformation Church, ready to deny any room for freedom. Therefore, today cities in those territories may be poorly managed as a consequence of the legacy of bad institutions (Acemoglu et al., 2005). More importantly, if the medieval experience of independence is related to the subsequent exposure to dominations due to some form of path dependence (Martin \& Sunley, 2010), our identification strategy may be weakened. To take into account this possibility, we have controlled for past dominations using indicators taken from Di Liberto and Sideri (2015). Data on political history are measured at provincial level, in line with the high fragmentation of the pre-unification borders. In particular, we consider two specifications. The first one includes a set of dummies that capture the domination whose influence was dominant at the local level, selected among those that were more relevant in the pre-unification Italian history (Spanish, Papal, Austrian, Venetian, Sabaudian). The second specification includes nine variables measuring the number of years that a specific regime has persisted at the local level in the period spanning from 1,100 to 1861. In this latter case, due to data availability, we were able to consider the following dominations: Norman, Swabian, Anjou, Spanish, Bourbon, Papal, Sabaudian, Austrian and Venetian. In both cases, the tests presented in Table 4 (Columns 3 and 4) confirm the robustness of our empirical strategy.

Again, our baseline estimates control only for current population. Nevertheless, the medieval experience of independence could have influenced the historical pattern of urbanization and, in turn, the political institutions in place 
over time. For instance, Percoco (2014) finds a relationship between past institutions and agglomeration process in Italy. Accordingly, we have also considered data on urbanization in XIV-XIX centuries from Malanima $(1998)^{18}$. In our sample, the correlation between actual population and the estimated level for 1,300 is high but less than perfect (0.51). However, Table 4 (Column 5) shows that our IV results persist after accounting for differences in population measured at various points of time $(1,300,1,400,1,500,1,600,1700,1800,1861)$.

Finally, while previous results are restricted to the Centre-North sample, we also run two additional IV exercises on our full sample of Italian cities. First, following Guiso et al. (2016), we consider the predicted probability of becoming a free-city, instead of its observed historical realization, as an instrument. ${ }^{19}$ Secondly, following de Blasio and Nuzzo (2010), we consider as an instrument a set of dummies for the historical traditions of civicness at provincial level. ${ }^{20}$ The results (reported in Table A5) confirm our previous evidence, even if the second estimation seems to be less robust with regard to the partial correlation of the instruments with our index of civic capital.

\section{5 | ESTIMATING THE POLITICAL PAYOFF FROM TRANSPARENCY}

After finding a significant effect of civic capital on the level of transparency of the Italian municipalities, we verify whether a political payoff for more transparent administrations exists and, in case it does, if it depends on civic capital.

Therefore, we test if the transparency performance of the Italian municipalities after the 2013 reform has changed the political payoff of incumbent administrations, specifically the probability of reelection. More formally, we regress the percentage of mayors and city administrators in 2012 (before the reform) that were still in power in 2017 (as five years is the usual length of the electoral cycle in Italy) on the CTI index. ${ }^{21}$ The initial specification in Table 5 (Columns 1, 4 and 7) includes our baseline set of controls for the socio-economic and geographic characteristics of municipalities (population and its square, ratio of people with secondary education, average income, Gini income inequality, digital divide, elevation and coastal location). In Table 5 (Columns 2, 5 and 8), we have also tested the robustness of our results by including a set of political variables at the initial period (age, gender, and education of mayor, party affiliation, and an index for second term), that could confound the effect of the performance in transparency on the probability of re-election. In our final specification of Table 5 (Columns 3, 6 and 9) we also add regional fixed effects to control for unobserved region-specific factors.

Overall, Table 5 suggests that the political payoff from being transparent is strictly related to the level of civic capital. Our results indicate that, in a high civic capital environment, a standard deviation increase in the CTI index raises the probability of remaining in power after five years by about $3.5 \%$. On the contrary, there is no significant political payoff for the transparency performance in low civic capital municipalities. In other words, the electoral punishment of political misbehavior in terms of transparency is observed only in municipalities characterized by high civic capital. This is in line with the idea that in environments where civic capital is high, citizens' attention toward government accountability is higher, and therefore, it might be politically unfeasible to disregard the demand for transparency. Combined with our previous findings, this evidence, albeit not a causal one, supports the hypothesis that the positive effect of civic capital on transparency can be partially due to the importance that civic people confer to the degree of transparency of their local administrators.

\footnotetext{
${ }^{18}$ Malanima (1998) provides some estimates of city population in Italy on a centennial basis over the period 1,300-1861. Population is censored to zero when it is lower than 5,000 inhabitants.

${ }^{19}$ To this end, we first consider the Centre-North sample and run a probit regression of the dummy "Commune" on a set of historical and geographical characteristics (elevation, difference in elevation within city territory, a dummy equals to 1 if the city was the seat of a Bishop before 1,000 , a dummy equals to 1 if the city was founded by the Etruscans, and dummies for city population in 1300). Then, the estimated coefficients are used to predict the probability to become a free-city among all the Italian cities.

${ }^{20}$ In particular, de Blasio and Nuzzo (2010) classify contemporary Italian provinces into five groups (communal republics, Signorie, Papal State, Kingdom of Sicily and peripheral territories), characterized by different degree of republicanism or autocracy at the beginning of the 14 th century.

${ }^{21}$ Data are taken from the Ministry of Home Affairs Archive and are available only for 479 cities in our sample.
} 

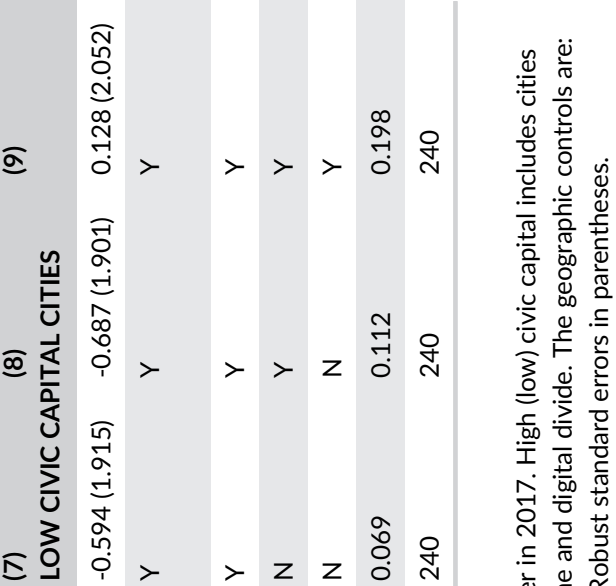

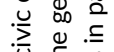

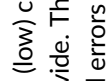

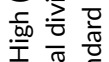

王 $\frac{\bar{\pi}}{\frac{\pi}{0}}$

귱

굳ำ

ऐัญ ำ วั

둥 둥

$\frac{\omega}{\pi}$ 苋

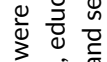

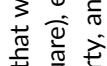

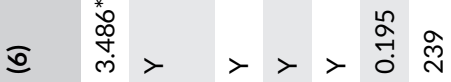

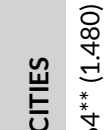

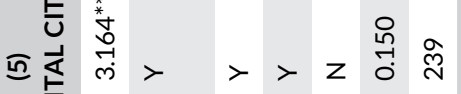

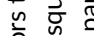

늄 \pm

苞

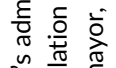

늘 है

을 을

ษ

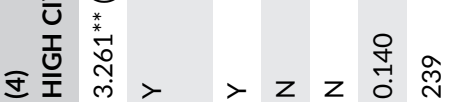

는 궁

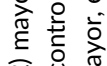

สิ

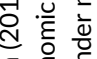

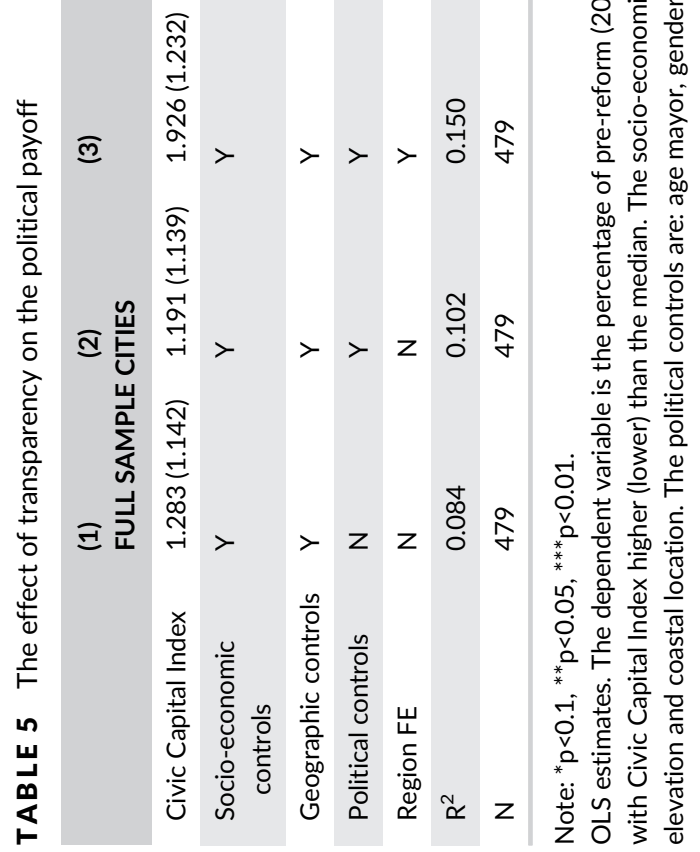




\section{6 | CONCLUDING REMARKS}

In this paper, we investigated the intertwined relationship among transparency, civic capital and political accountability in a large sample of Italian municipalities. On the one hand, we show that civic capital positively affects the level of transparency of local governments; on the other hand, we provide novel evidence that transparency increases the probability for the local administrators to be reelected only in the municipalities characterized by a high degree of civic capital. In other words, the accumulation of civic capital represents a powerful incentive to induce local governments to be more transparent, and therefore more accountable, increasing and improving the information available to citizens.

\section{REFERENCES}

Acemoglu, D., Johnson, S. \& Robinson, J.A. (2005) Institutions as a Fundamental Cause of Long-Run Growth. In: Aghion, P. \& Durlauf, S. (Eds.) Handbook of Economic Growth 1A. North-Holland.

Aguiar-Conraria, L., Magalhães, P.C. \& Veiga, F.J. (2019) Transparency, Policy Outcomes, and Incumbent Support. Kyklos, 72 (3), 357-380.

Albalate del Sol, D. (2013) The institutional, economic and social determinants of local government transparency. Journal of Economic Policy Reform, 16(1), 90-107.

Albanese, G. \& de Blasio, G. (2016) Civic Capital and Development: Italy, 1951-2001. Politica Economica - Journal of Economic Policy, 1, 47-64.

Albanese, G., Cioffi, M. \& Tommasino, P. (2019) Legislators' Behaviour and Electoral Rules: Evidence from an Italian Reform. European Journal of Political Economy, 59, 423-444.

ANAC - Autorità Nazionale Anticorruzione. (2015) Relazione Annuale 2014.

Araujo, J.F.F.E. \& Tejedo-Romero, F. (2016) Local government transparency index: determinants of municipalities' rankings. International Journal of Public Sector Management, 29(4), 327-347.

Banfield, E. (1958) The Moral Basis of a Backward Society. Free Press.

Barone, G. \& de Blasio, G. (2010) II capitale sociale. In II Mezzogiorno e la politica economica dell'Italia, Seminari e Convegni, 4, Banca d'Italia.

Batinti, A., Andriani, L. \& Filippetti, A. (2019) Local Government Fiscal Policy, Social Capital and Electoral Payoff: Evidence across Italian Municipalities. Kyklos, 72 (4), 503-526.

Bault, N., Fahrenfort, J.J., Pelloux, B., Ridderinkhof, K.R. \& van Winden, F. (2017) An affective social tie mechanism: Theory, evidence, and implications. Journal of Economic Psychology, 61, 152-175.

Belloni, A., Chernozhukov, V. \& Hansen, C. (2014) Inference on Treatment Effects after Selection amongst HighDimensional Controls. Review of Economic Studies, 81(2), 608-650.

Bertelli, A. \& Pietrowsky, S. (2010) Measuring municipal transparency. Unpublished paper prepared and presented at 14th IRSPM conference Bern, Switzerland on 1 April.

Bigoni, M., Bortolotti, S., Casari, M., Gambetta, D. \& Pancotto F. (2016) Amoral familism, social capital, or trust? The behavioural foundations of the Italian North-South divide. Economic Journal, 126, 1318-1341.

Bracco, E., De Paola, M. \& Green C.P. (2015) Long lasting differences in civic capital: Evidence from a unique immigration event in Italy. Journal of Economic Behavior \& Organization, 120, 160-173.

Cartocci, R. \& Vanelli, V. (2015) Una mappa del capitale sociale e della cultura civica in Italia, in L'Italia e le sue regioni. L'età repubblicana, Società Istituto Enciclopedia Italiana Treccani, 17-36.

Conley, T.G. (1999) GMM Estimation with Cross Sectional Dependence. Journal of Econometrics, 92(1), 1-45.

Cucciniello, M., Porumbescu, G.A. \& Grimmelikhuijsen, S. (2016) 25 Years of Transparency Research: Evidence and Future Directions. Public Administration Review, 77(1), 32-44.

de Blasio, G. \& Nuzzo, G. (2010) Historical Tradition of Civicness and Local Economic Development. Journal of Regional Science, 50(4), 833-857.

de Blasio, G., Scalise, D. \& Sestito, P. (2014) Universalism vs. particularism: a round trip from sociology to economics. Questioni di Economia e Finanza (Occasional Papers), 212, 6-37.

de Fine Licht, J., Naurin, D., Esaiasson, P. \& Gilljam, M. (2014) When Does Transparency Generate Legitimacy? Experimenting on a Context-Bound Relationship. Governance, 27 (1). 111-134.

De Luca, G. (2012) Trading Money and Empire Building in Spanish Milan (1570-1640). In: Cardim, P., Herzog, T., Ruiz Ibáñez, J.J. \& Sabatini, G. (Eds.) Polycentric monarchies. How did Early Modern Spain and Portugal Achieve and Mantain a Global Hegemony? Sussex Academic Press.

Di Liberto, A. \& Sideri, M. (2015) Past Dominations, Current Institutions, and the Italian Regional Economic Performance. European Journal of Political Economy, 38(C), 12-41. 
Etzioni, A. (2010) Is Transparency the Best Disinfectant? Journal of Political Philosophy, 18 (4), 389-404.

Etzioni, A. (2014) The Limits of Transparency. Public Administration Review, 74(6), 687-688.

Fadda, I., Paglietti, P., Reginato, E. \& Pavan, A. (2018) Analysing Corruption: Effects on the Transparency of Public Administrations. In: Borgonovi, E., Anessi-Pessina, E., Bianchi, C. et al. (Eds.) Outcome-Based Performance Management in the Public Sector. Springer International Publishing.

Galli, E., Rizzo, I. \& Scaglioni, C. (2017) Transparency, Quality of Institutions and Performance in the Italian Municipalities. WP11/2017/DE/UECE, ISEG - University of Lisbon.

Galli, E., Rizzo, I. \& Scaglioni, C. (2019) Transparency and socio-political environment in the large Italian municipalities. In: Bianco, A., Gnaldi, M. \& Conigliaro, P. (Eds.) Italian Studies on Quality of Life. Springer.

Galli, E., Rizzo, I. \& Scaglioni, C. (2020) Is Transparency Spatially Determined? An Empirical Test for the Italian Municipalities. Applied Economics. forthcoming.

Giordano, R. \& Tommasino, P. (2013) Public Sector Efficiency and Political Culture. FinanzArchiv, 69(3), 256-288.

Grimmelikhuijsen, S.G. \& Meijer A.J. (2014) Effects of Transparency on the Perceived Trustworthiness of a Government Organization: Evidence from an Online Experiment. Journal of Public Administration Research and Theory, 24(1), 137-157.

Grumet, J. (2014) City of Rivals: Restoring the Glorious Mess of American Democracy. Globe Pequot Press.

Guiso, L., Sapienza, P. \& Zingales, L. (2008) Social capital and good culture, Marshall Lecture. Journal of the European Economics Association, 6, 295-320.

Guiso, L., Sapienza P. \& Zingales L. (2011) Civic Capital as the Missing Link. In: Benhabib, J., Bisin, A. \& Jackson, M.O. (Eds.) Social Economics Handbook. Vol. 1A. North-Holland.

Guiso, L., Sapienza, P. \& Zingales, L. (2016) Long term persistence. Journal of the European Economic Association, 14(6), 1401-1436.

Heald, D. (2006) Varieties of Transparency. In: Hood, C. \& Heald, D. (Eds.) Transparency: The Key to Better Governance? Oxford University Press, pp. 25-43.

Istat. (2014) Rapporto Bes 2014: il benessere equo e sostenibile in Italia.

Jottier, D. \& Heyndels, B. (2012) Does social capital increase political accountability? An empirical test for Flemish municipalities. Public Choice, 150 (3-4), 731-744.

Kamei, K., Putterman, L. \& Tyran, J.-R. (2019) Civic Engagement as a Second-Order Public Good: The Cooperative Underpinnings of the Accountable State. mimeo.

Malanima, P. (1998) Italian Cities 1300-1800. A quantitative approach. Rivista di Storia Economica, XIV(1), 91-126.

Malanima, P. (2005) Urbanisation and the Italian Economy during the Last Millennium. European Review of Economic History, 9(1), 97-122.

Malanima, P. (2011) The Long Decline of a Leading Economy: GDP in Central and Northern Italy, 1300-1913. European Review of Economic History, 15(2), 169-219.

Malito, D. (2014) Measuring Corruption Indicators and Indices. European University Institute Working Paper 2014/13, Robert Schuman Centre for Advance Studies.

Martin, R. \& Sunley, P. (2010) The Place of Path Dependence in an Evolutionary Perspective on the Economic Landscape. In: Boschma, R. \& Martin, R. (Eds.) Handbook of Evolutionary Economic Geography. Edward Elgar, Cheltenham.

Meijer, A.J., T'Hart, P. \& Worthy, B. (2015) Assessing Government Transparency: An Interpretive Framework, Administration \& Society. Published electronically on August 19.

Nannicini, T., Stella, A., Tabellini, G. \& Troiano U. (2013) Social Capital and Political Accountability. American Economic Journal: Economic Policy, 5(2): 222-250.

Nifo, A. \& Vecchione, G. (2014) Do institutions play a role in skilled migration? The case of Italy. Regional Studies: 1628-1649.

OECD. (2015) Government at a glance, OECD.

OECD. (2017) Government at a glance, OECD.

Oster, E. (2019) Unobservable Selection and Coefficient Stability: Theory and Evidence. Journal of Business \& Economic Statistics, 37(2), 187-204.

Percoco, M. (2014) Path dependence, Institutions and the Density of Economic Activities: Evidence from Italian Cities. Papers in regional science, 93(1), 53-76.

Pernagallo, G. \& Torrisi, B. (2020) A logit model to assess the transparency of Italian public administration websites. Government Information Quarterly, 37, 1-12.

Piotrowski, S.J. \& Van Ryzin, G.G. (2007) Citizen Attitudes toward Transparency in Local Government. The American Review of Public Administration, 37(3), 306-323.

Porumbescu, G. (2015) Does Transparency Improve Citizens' Perceptions of Government Performance? Evidence From Seoul, South Korea. Administration \& Society, 49(3), 443-468.

Putnam, R. (1993) Making Democracy Work: Civic Tradition in Modern Italy. Princeton University Press. 
Rupasingha, A., Goetz, S.J. \& Freshwater, D. (2006) The production of social capital in US counties. Journal of Socio-Economics, 35(1), 83-101.

Sequeira, S. (2012) Advances in Measuring Corruption in the Field. In: Serra, D. \& Wantchekon, L. (Eds.) New Advances in Experimental Research on Corruption. Emerald Group Publishing Limited.

SOSE. (2016) The Italian way towards Standard Expenditure Needs. http://www.opencivitas.it/progetto-fabbisogni-standard

Stock, J. H. \& Yogo, M. (2005) Testing for Weak Instruments in Linear IV Regression. In: Andrews, D.W.K. \& Stock, J.H. (Eds.) Identification and Inference for Econometric Models: Essays in Honor of Thomas Rothenberg. Cambridge University Press.

Welch, E., Hinnant, C. \& Moon, C. (2005) Linking Citizen Satisfaction with E-Government and Trust in Government. Journal of Public Administration Research and Theory, 15, 371-391.

\section{SUPPORTING INFORMATION}

Additional supporting information may be found online in the Supporting Information section at the end of this article.

How to cite this article: Albanese G, Galli E, Rizzo I, Scaglioni C. Transparency, Civic Capital and Political Accountability: A Virtuous Relation? Kyklos. 2021;1-15. https://doi.org/10.1111/kykl.12260 